\title{
TRAINING OF THE STATE PRESIDENT'S UNIT
}

\section{Lt Cdr E.M. Meyers*}

The primary function of the State President's Unit is to protect the head of state - not his person as is generally believed, but his authority over the state. Ironically, the ceremonial performances of the State President's Unit lead people to believe that they are only capable of doing drill exercises.

However, upon investigating the training they receive during National Service, one soon changes one's opinion. The sentries are trained as soldiers who can protect their country against attacks from the outside, as well as against internal unrest. The ceremonial function is also of great importance and a high standard of training for the Unit, as home guard and as guard of honour, is maintained.

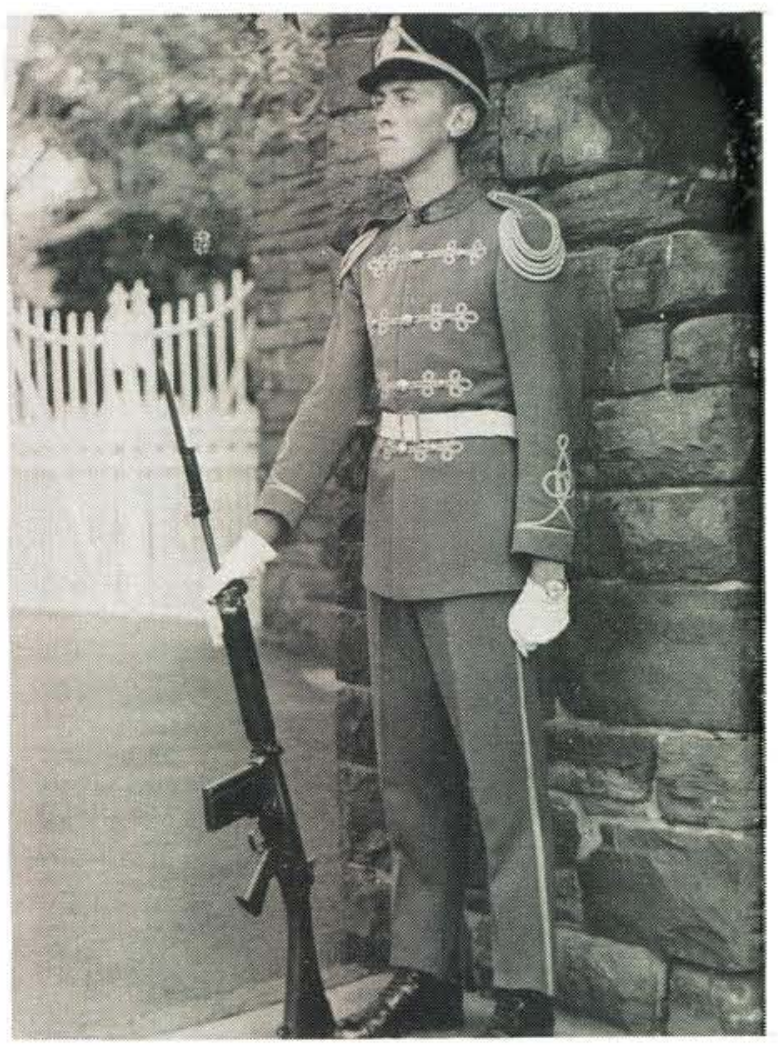

Staatspresidentswag by die Kerkstraathek van die Presidensie waar al die vroeëre Presidente tuis was

The State President's Guard at the Church Street, gate of the Presidency where all previous presidents have resided

\section{As Home Guard}

As home guard, much of their time is occupied by constant duty at the homes of the State Presi- dent in Pretoria, Cape Town, Bloemfontein or Durban while the State President is in residence.

The guards relieve one another every 24 hours and, during a stint of duty, a guard is active for four shifts of 2 hours each. In warm weather these shifts are reduced to one hour only.

The changing of the guard occurs at $09 \mathrm{~h} 00$ every morning in front of the home of the State President while he is in residence and the guard is responsible for the daily hoisting and striking of the State President's Flag.

Apart from the above-mentioned functions, the home guards also act as orderlies in the household and office of the State President, such as receiving visitors at the door; taking telephone messages; collecting and delivering mail and acting as messengers at the office.

\section{As Guard of Honour}

Since the establishment of the State President's Guard, it has become very well-known to the public, due to numerous successful performances as the personal ceremonial guard of the State President.

They have performed at the inaugurations of five State Presidents - with the exception of President C.R. Swart, the first State President.

Other official performances include the Opening of Parliament; garden parties; visits by heads of state, such as that of President Banda of Malawi in 1971; the visit of the supreme commander of the Portuguese forces in Angola in 1972 and that of President Stroessner of Paraguay in 1974. Other appearances include those at state funerals and when foreign ambassadors present their credentials to the State President.

All the occasions at which the Unit performs, especially the annual official Opening of Parliament in Cape Town, attract so much attention that the impression is created that the Unit merely concentrates on doing drill work. However, when the nature of their training is investigated, the opposite proves to be true. 


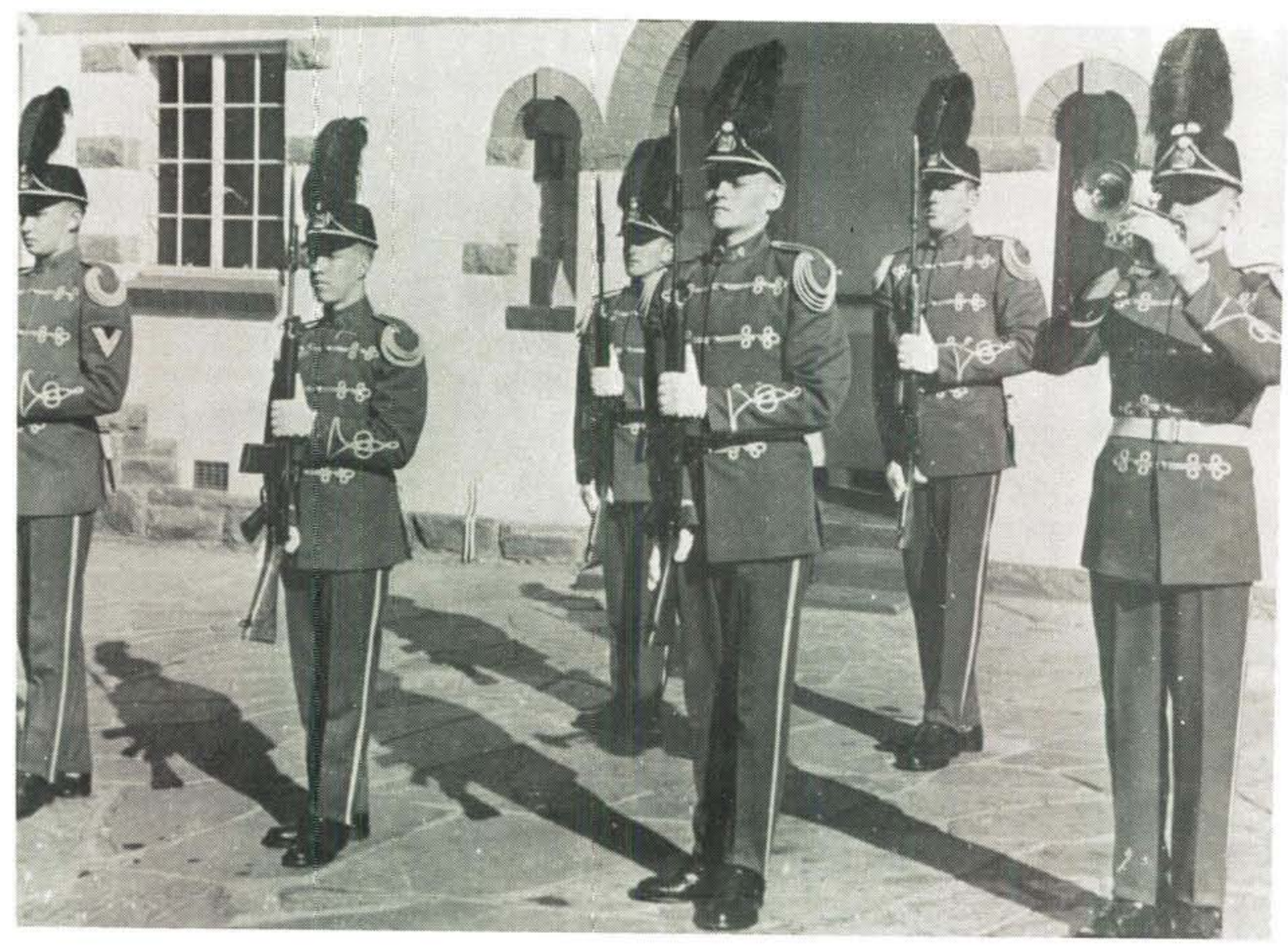

Wagwisseling van die Staatspresidentswag voor die Presidensie

Changing of the guard in front of the Presidency

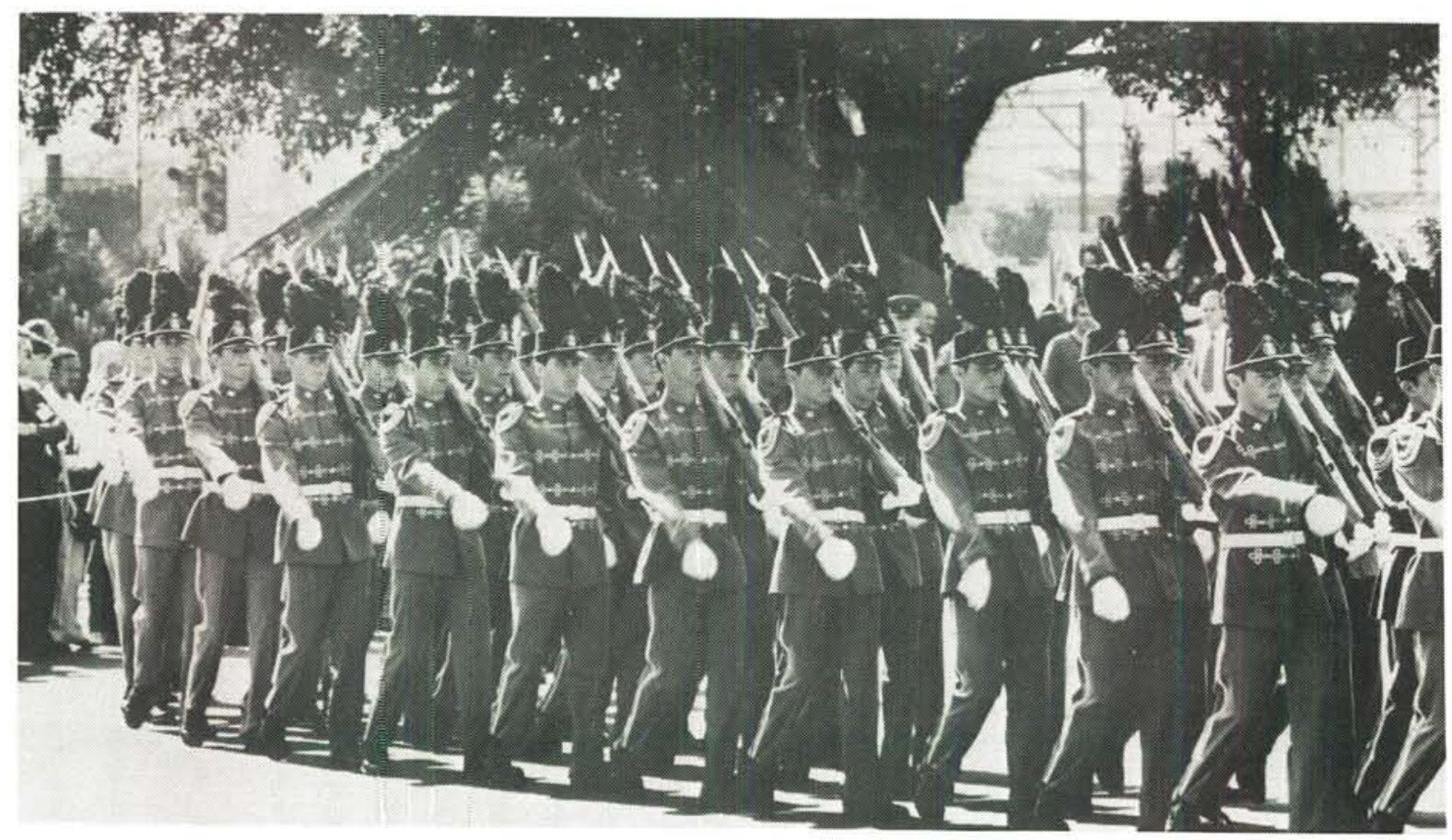

Inhuldigingseremonie van die nuwe Staatspresident 14 September 1984 Inauguration ceremony of the new State President on 14 September 1984 


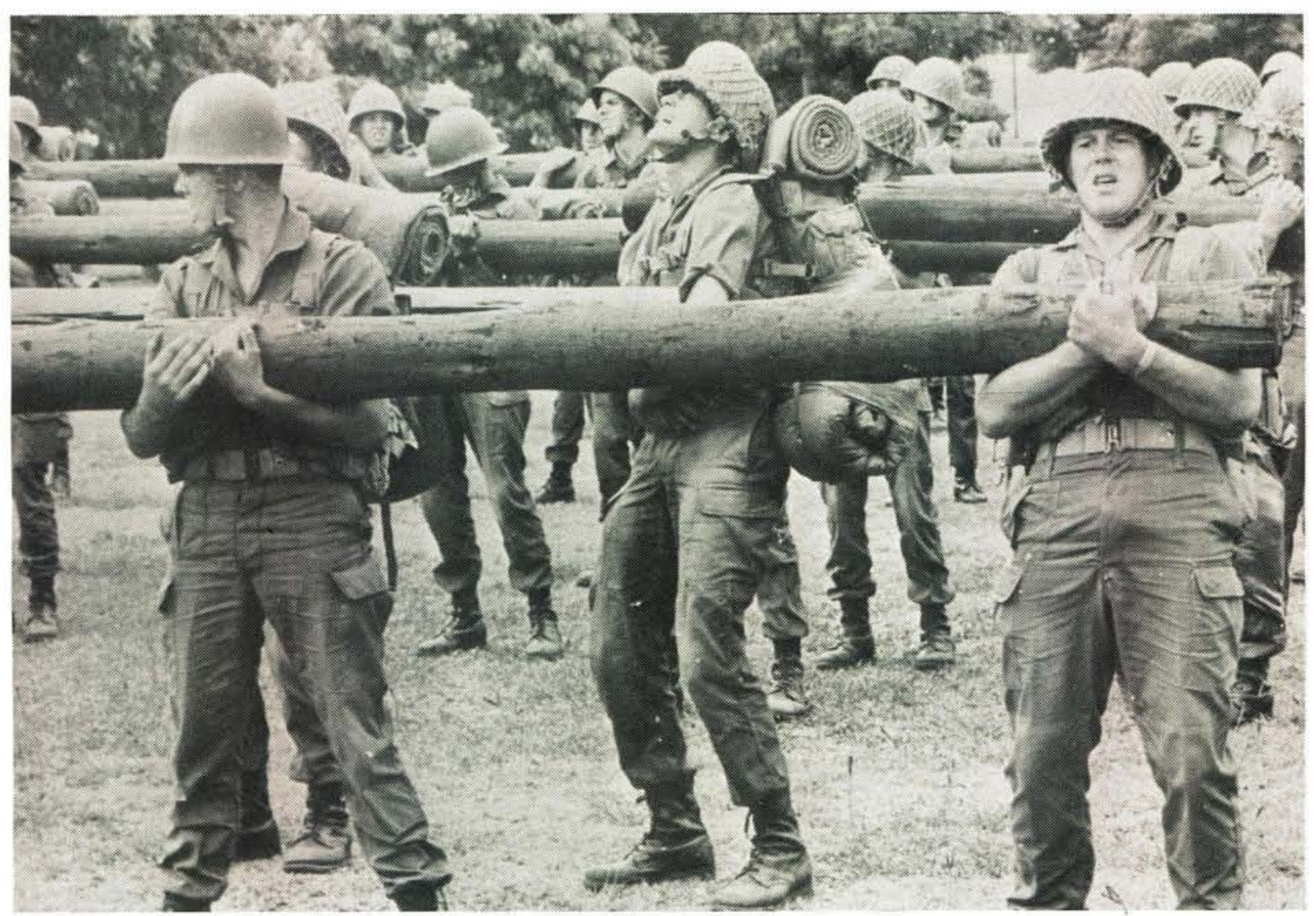

Oefening met pale deur lede van die SP Wag

Members of the State President's Guard exercising with poles

\section{Training}

Due to the fact that the State President's Unit is an infantry unit, members are trained as proper infantrymen. The following divisions can be distinguished: vocational training (weapons, management, maintenance, etc.), counter-insurgency operations (urban), counter-insurgency operations (rural), conventional warfare and ceremonial training.

After basic training, individual training takes place, during which attention is given to, inter alia, the training of clerks, radio operators, etc. By means of management and maintenance courses, some members are able to qualify as managers. Weapon training includes the handling and use of all platoon weapons and some are trained in the use of mortars and other highly-specialised weapons. Others also receive training in the 81 and $60 \mathrm{~mm}$ mortars and other specialist weapons. Other aspects of training include conventional and counter-infiltration operations, map-reading and initiative training.
No doubt whatsoever exists that the training is indeed very severe: the parade-ground work is exhausting, and pushes physical and spiritual endurance and self-discipline to the utmost limit.

Apart from the above-mentioned training, it is also essential that daily attention is given to drill exercises. The average degree of fitness in the Unit is of the highest in the Army.

A great deal of time is also spent on religious orientation and civilian guidance. Daily activities commence with a prayer parade. Sports and recreational training is also strongly emphasised.

Since the Head of State of the Republic of South Africa is being served, only the best sentries will suffice. It is for this reason that the training is so gruelling, and that only a few servicemen are eligible for selection.

\section{Training Incentives}

Certain specifications regarding the training of 


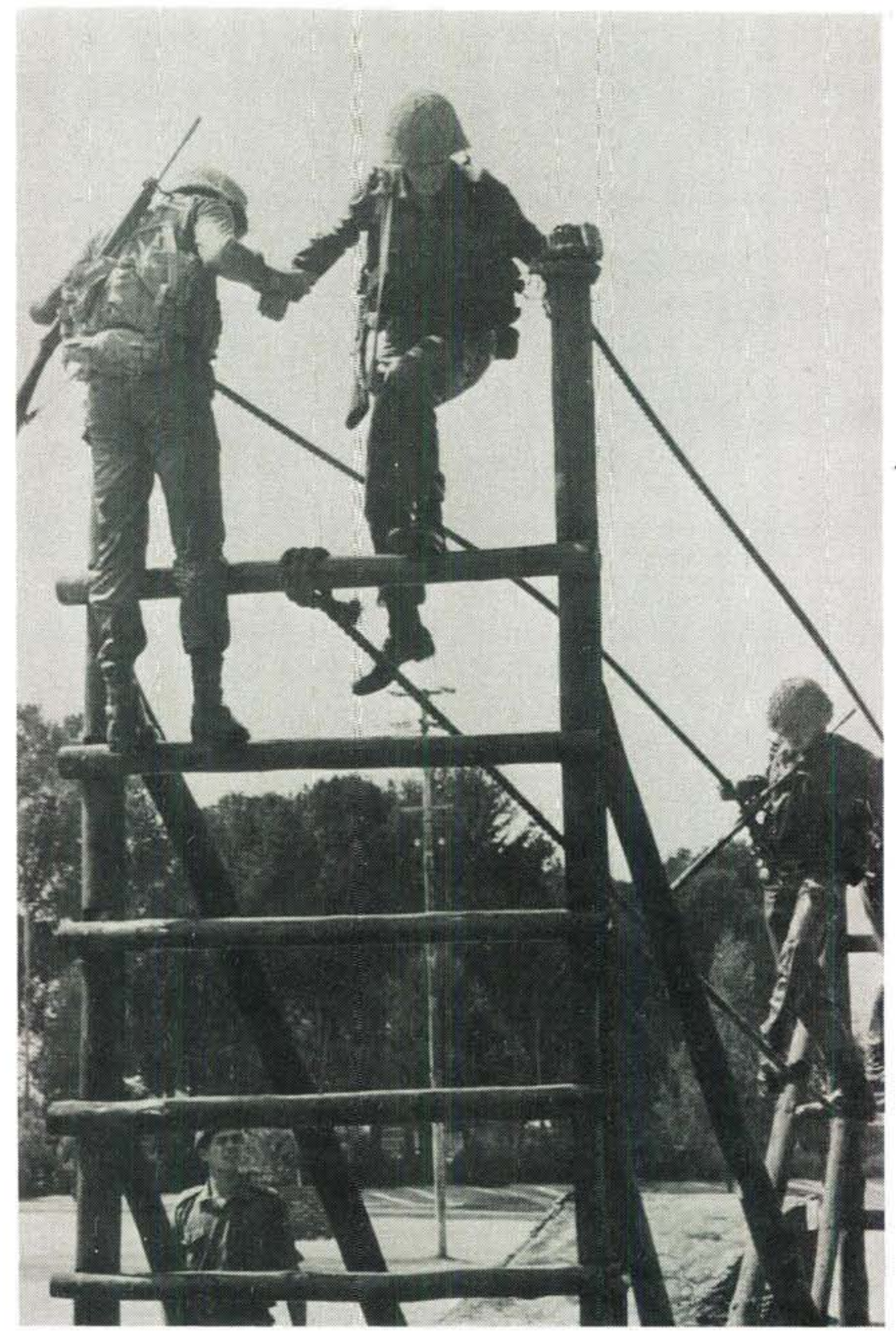

Tou-loop en pale klim tydens basiese opleiding Rope-walking and pole-climbing during basic training

the State President's Unit are demanded. These include an average of 190 points in the Chief of the Army's shooting competitions; a fitness standard of $75 \%$; a maximum number of accident-free kilometres; irreproachable loyalty towards the SADF; and a high standard in ceremonial work.

As far as individual goals are concerned, incentive measures are provided to motivate people to obtain good results. Firstly, the State President's Guard Training Diploma was awarded upon completing National Service and in compliance with certain requirements. Secondly, a National Serviceman had to qualify for an R4 rifle shooting bar. A State President's Guard blazer was also awarded to members who met certain requirements after completing National Service. A number of trophies are awarded for achievements, such as best sportsman, best section commander, best marksman, neatest troop, as well as a trophy for the troop who shows the best progress. 


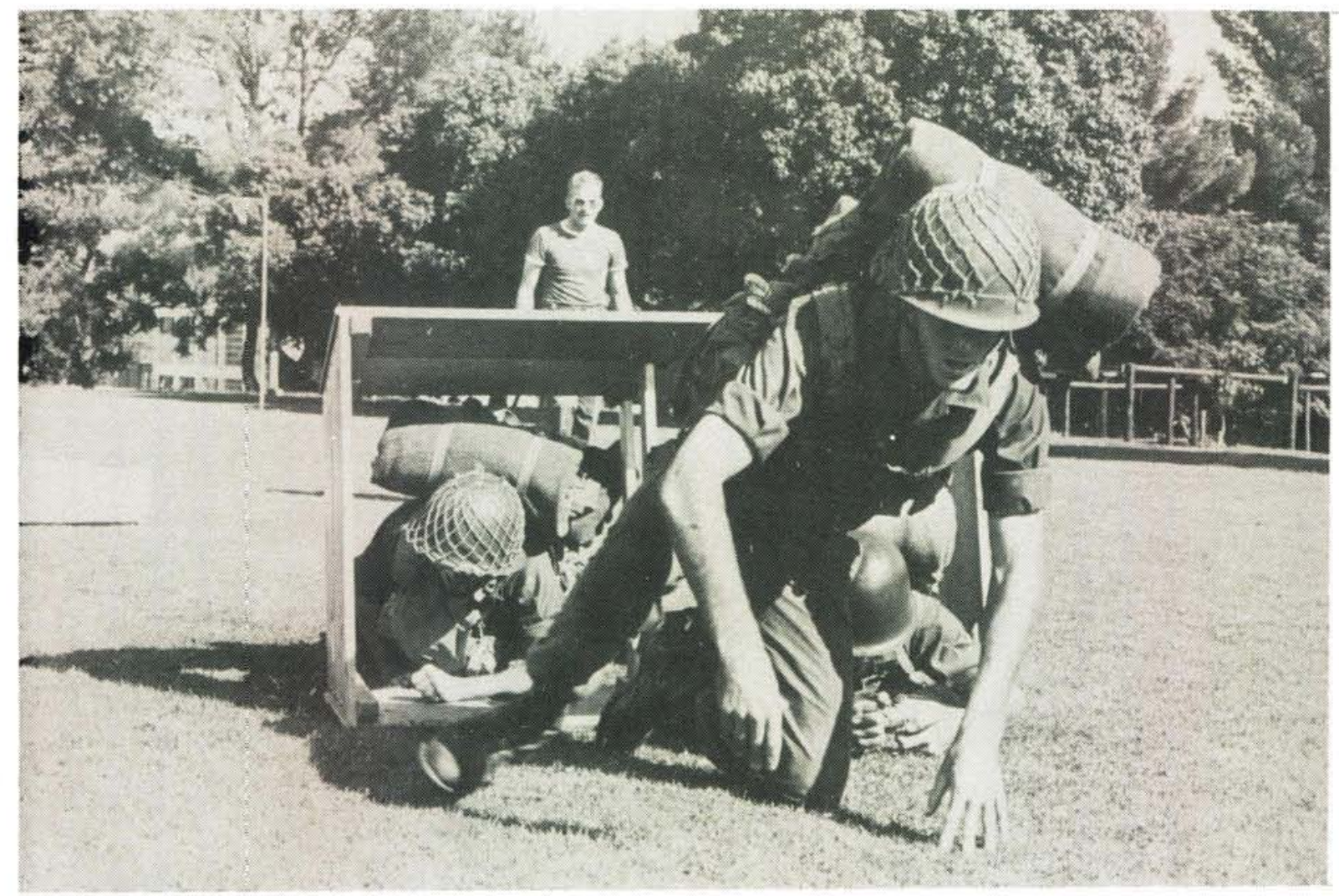

Hinderniswedloop van die SP Wag tydens opleiding

An obstacle race: part of the training of the State President's Guard

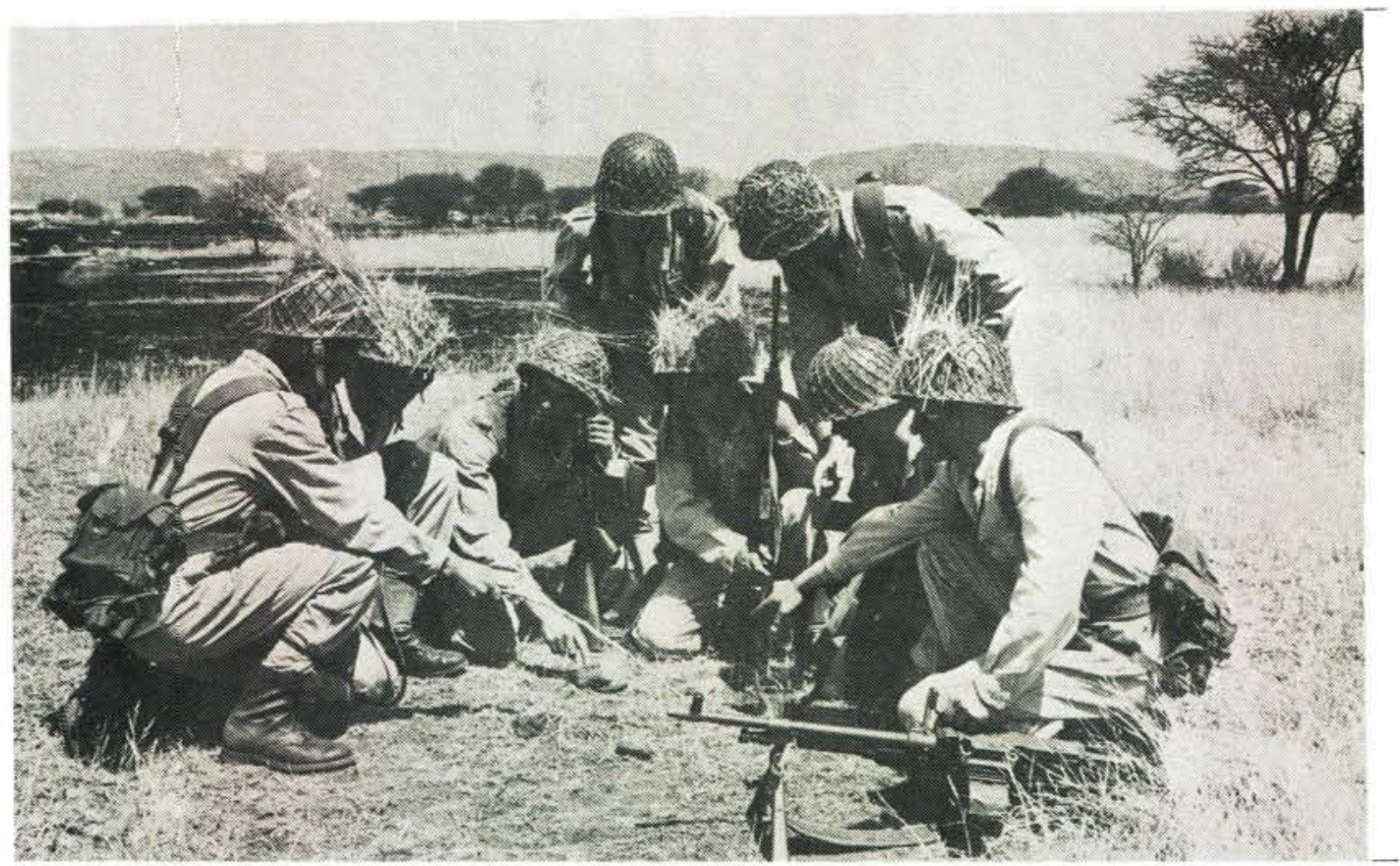

Veldopleiding van die SP Wag

The State President's Guard undergoes field training 


\section{TRAINING OPLEIDING}

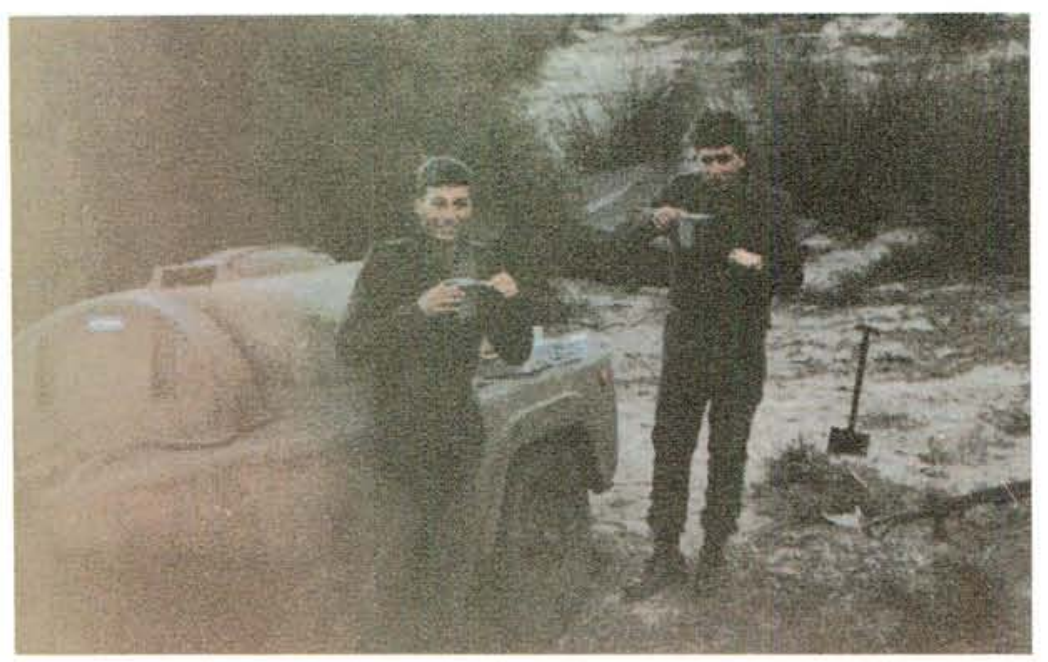

\section{Etenstyd tydens ' $n$ veldoefening van die eenheid.}

Mealtime during the Unit's field exercise.
Draf met buiteband tydens opleiding.

Running with a tyre during training.

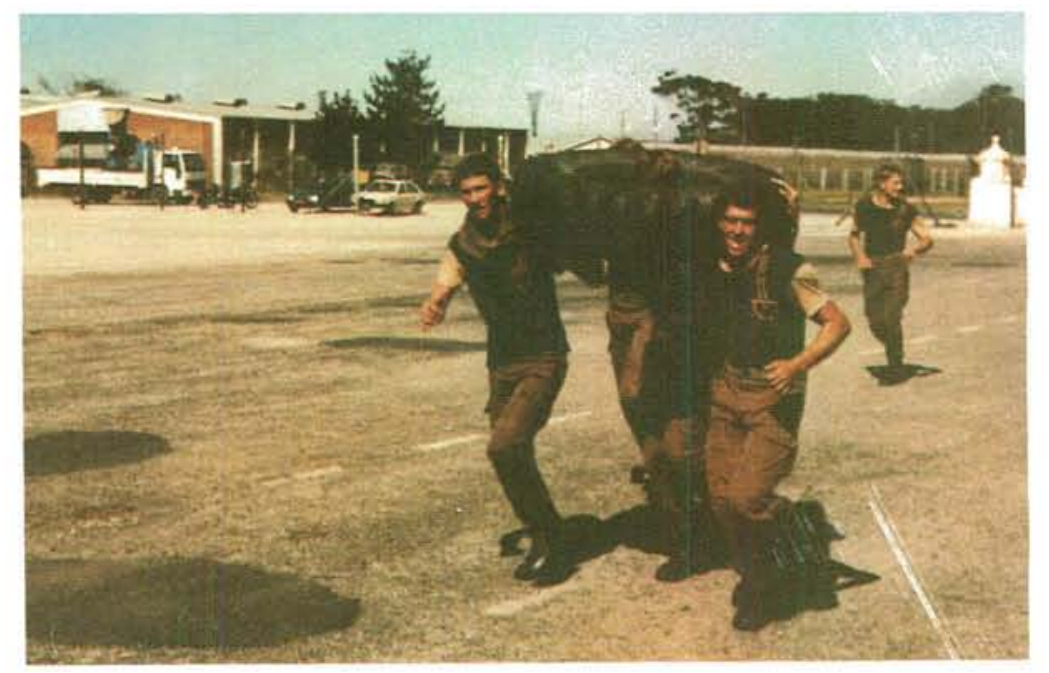

SP-eenheid

dagkommando.

Veldoefening by

Doornkop.

State President's Unit day commando during a field exercise at

Doornkop. 


\section{STATE PRESIDENT'S FLAG STAATSPRESIDENTSVLAG}

SP-eenheid op parade met Staatspresidentsvlag (regs) by opening van die Parlement, 1986.

State President's Unit on parade. The State President's Flag is displayed (right), at the Opening of Parliament, 1986.

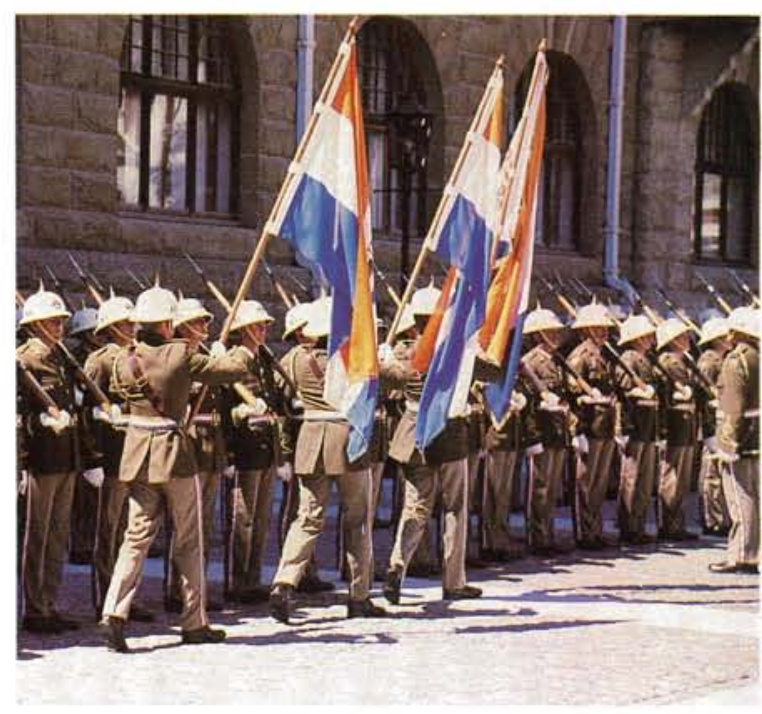

Vorige Staatspesidentsvlag wat uit ' $n$ blou agtergrond bestaan het met die seremoniële

Staatspresidentswapen daarop.

The previous State President's Flag consisting of a blue field with the ceremonial badge of the State President. 


\section{Border Duties of the State President's Guard}

On 22 October 1977 the State President's Guard, under the command of Captain Nawn, departed for the operational area. On the second day after their attachment, they were involved in a mine accident and Captain Nawn and 5 members of the Guard were injured.

During the two-year period of National Service, every member of the Unit spends approximately 10-12 months in the operational area. The group which returned on 29 October 1979, had been at the border since 2 January 1979. Under normal circumstances, border duty lasts for only three months but since the State President's Guard is so well-trained, supreme command usually chooses to keep them there for a longer period if they are willing to stay.

A few major operations in which members of the Unit participated, were the attacks on 'Moscow' and 'Vietnam' in May 1979, and on Katima Mulilo in August 1978 during a hot pursuit operation. Every time a unit of the State President's Guard has been to the operational area, it has been involved in a contact with SWAPO.

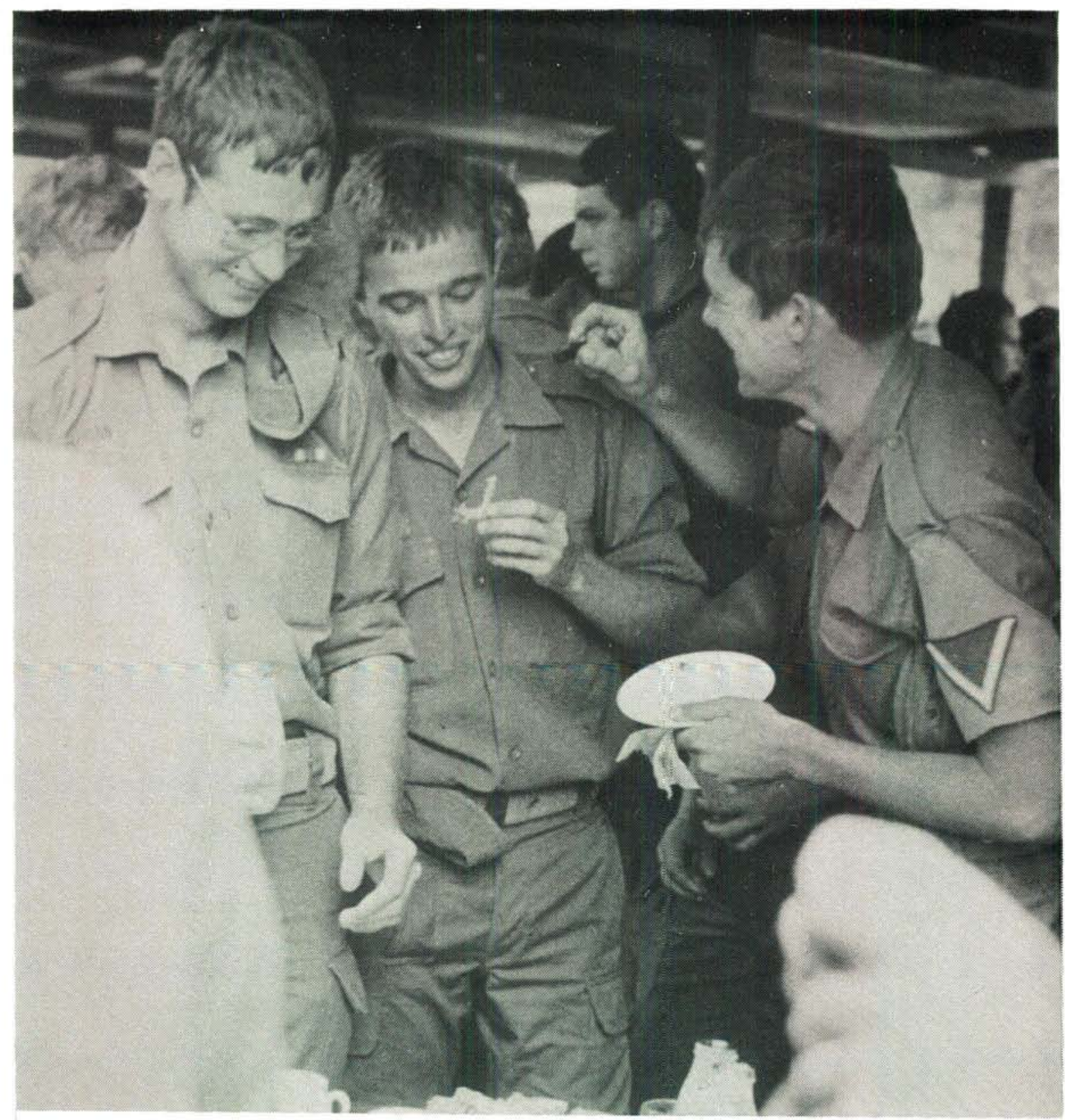

Etenstyd

Mealtime 


\section{Officers}

The State President's Guard is also responsible for the image of the SADF at ceremonial level and a better quality unit personnel is required than for other units, because they have constant contact with dignitaries.

\section{Officers Commanding}

The first officer commanding was Major J.C. Swarts, who was the head of the State President's Guard since its inception in May 1967. In March 1971 he was succeeded by Major S.J.P.K. Steenkamp, who acted as officer commanding until May 1973. After him, the following persons were appointed as officers commanding: Major C.J. Lourens (May 1973 - January 1977); Major F.A. Botes (January 1977 - January 1980); Major J.H. Nawn (January 1980 - December 1981); Major H.A. de Witt (January 1982 January 1985); Major P.J. de Witt (January 1985 - January 1986).

In the meanwhile, the status of the Guard was upgraded to that of a unit and the officer commanding who took over in January 1986 also received higher status. In January 1986 Commandant J.F. Weilbach took over as officer commanding, a position which he at present still holds.

\section{Base changes}

Upon the inception of the State President's Guard in 1967, it was attached to the Army Gymnasium in Pretoria. When the latter was relocated at Heidelberg, the Guard fell under the South African Medical Service Training Centre.

Due to accommodation problems, the Guard moved to Wonderboom to the location of 4 Provost Company in January 1969. In October 1971 they moved to the new location of the Army Gymnasium at Heidelberg. Since the Guard was consequently located too far from Pretoria, where most of its functions had to be performed, they moved back to Pretoria once again in 1973 , where they were accommodated at 2 Signal Regiment until better facilities became available in May 1974. Later the Unit was attached to the South African Army College, where it still is at present.

* Lt Cdr E.M. Meyers, MA (HOD) is attached to the Military Information Bureau, SADF.

\footnotetext{
Sources

1. Brochure on the State President's Guard: 15 years: compiled by the SADF Documentation Service.

2. Files compiled by the State President's Guard.

3. Interview with the officer commanding: Maj P. de Witt on 3rd June 1985.

4. Notes compiled by the office of the State President.
} 